\title{
The Characterization of Hyalochlorella marina gen. et sp.nov. a New Colourless Counterpart of Chlorella
}

\author{
By R. O. POYTON \\ Microbiology Group and Department of Botany, \\ University of California, \\ Berkeley, California 94720, U.S.A.
}

(Accepted for publication 22 April 1970)

SUMMAR Y

Hyalochlorella marina is described as the type species of a new colourless genus of the chlorococcalean algae. It is a morphological and developmental counterpart of Chlorella and analogous to Prototheca, the known colourless counterpart. Hyalochlorella is distinguishable from Prototheca by its mode of autospore discharge, its possession of a large centric or eccentric vacuole, a Ruthenium Red positive wall and its lack of pectinaceous interstitial ground substance in the mature sporangium. Its developmental cycle is simple, involving a period of growth followed by cytokinesis. Nuclear division occurs concomitantly with growth; cytokinesis involves the segmentation of a multinucleate protoplast into uninucleate daughter protoplasts (preautospores) by simultaneous multiple fission. Daughter cell number, although variable, is usually an integral of $2^{n}$ or $2^{n}-2^{n-2}$. Numbers in the $2^{n}-2^{n-2}$ series are believed to result from the degeneration of one nucleus in the tetranucleate stage followed by subsequent growth and division.

\section{INTRODUCTION}

The existence of morphological and developmental colourless counterparts of many unicellular algae has been known for some time (Pringsheim, I963). A number of achloric counterparts to Chlorella have been reported. These have been either isolated from nature as members of the genus Prototheca, or in the laboratory as spontaneous (Beijerinck, 1904) or induced mutants of various Chlorella strains (Granick, I948; Butler, 1954). Prototheca and Chlorella differ in their mode of nutrition, storage products and requirements for thiamine. Like Prototheca, the colourless mutants of Chlorella so far examined do not fix $\mathrm{CO}_{2}$ autotrophically and do not store starch but, unlike Prototheca, they do not require thiamine. In nature, Prototheca has been isolated from slime fluxes of trees (Krüger, I 894; Phaff, Yoneyama \& Do Carmo-Sousa, I964), the faeces and fingernails of man (Ashford, Ciferri \& Dalmau, 1930), potato skin (Negroni \& Blaisten, I94I), and waste stabilization ponds (Cooke, I968a). Chlorella is a common inhabitant of the soil as well as aquatic and marine environments where, with the exception of zoochlorellae symbionts, it is free-floating.

During the past six years, colourless coccoid forms frequently have been found in attempts to isolate marine fungi (Fuller \& Poyton, 1964; Poyton, 1970). These have been isolated from sea water and from the surface of littoral filamentous algae. Initially, some of these forms were considered to belong to the poorly characterized 
protistan genus, Dermocystidium (Fuller \& Poyton, 1964; Goldstein \& Moriber, I966). Recently, however, a closer look at the developmental cycle and morphology of these forms has led to the conclusion that they are morphological and developmental counterparts of Chlorella, yet distinct from Prototheca, its known colourless counterpart. The following work was undertaken to characterize these forms more fully and to determine the extent to which they differed from Prototheca.

\section{METHODS}

Organisms. The source and date of isolation for each strain assigned to Hyalochlorella marina are listed in Table I. Strains 66-6A and 69-I A have been deposited in the Indiana University Algal Culture Collection. The following strains of the genus Prototheca were used for comparative studies with $H$. marina.

68-13A $P$. zopfii strain YB 833 of the Northern Utilization and Developmental Laboratory. Received from Indiana University Culture Collection as strain 1438 .

68-14A P. zopfii strain 263/5 of the Cambridge University Algal Culture Collection. Received from Indiana University Algal Culture Collection as strain 328.

68-15A P. zopfii strain IV 7300 of the Hopkin's Marine Station. Received from Dr C. B. van Niel.

68-I6A $P$. zopfii strain IV 7322 of the Hopkin's Marine Station. Received from Dr C. B. van Niel.

68-I7A P. zopfii strain IV732I of the Hopkin's Marine Station. Received from Dr C. B. van Niel.

68-I8A P. chlorelloides strain 263/I of the Cambridge University Algal Culture Collection. Received from the Indiana University Algal Culture Collection as strain 178 .

68-I9A $P$. chlorelloides strain IV73I I of the Hopkin's Marine Station. Received from Dr C. B. van Niel.

68-20A P. pastoriensis strain IV 7342 of the Hopkin's Marine Station. Received from Dr C. B. van Niel.

68-2I A P. pastoriensis strain IV734I of the Hopkin's Marine Station. Received from Dr C. B. van Niel.

68-22A P. stagnora strain 62-344 of Dr W. B. Cooke. Received from the Indiana University Algal Culture Collection as strain 1442.

68-23A P. moriformis strain $263 / 2$ of the Cambridge University Algal Culture Collection. Received from the Indiana University Algal Culture Collection as strain 288.

68-24A $P$. wickerhamii strain YB 4330 of the Northern Utilization and Development Laboratory. Received from the Indiana University Algal Culture Collection as strain 1553 .

68-25A P. portoricensis strain 1075 of $\mathrm{Dr}$ B. K. Ashford. Received from the Indiana University Algal Culture Collection as strain 289.

68-26A P. portoricensis var. triporus strain 1095 of Dr B. K. Ashford. Received from the Indiana University Algal Culture Collection as strain 327.

68-27A Prototheca sp. strain IV736I of the Hopkin's Marine Station. Received from Dr C. B. van Niel.

68-28A Prototheca sp. strain IV735I of the Hopkin's Marine Station. Received from Dr C. B. van Niel. 
68-29A Prototheca sp. strain IV 737I of the Hopkin's Marine Station. Received from Dr C. B. van Niel.

Three spontaneous colourless mutants of Chlorella sp. were also used in comparative studies with Hyalochlorella marina: 69-7A, 69-8 A, 69-9A derived from Chlorella sp. strain 820 of the Indiana University Algal Culture Collection.

Table I. Sources of Hyalochlorella isolates

\begin{tabular}{|c|c|c|c|}
\hline Strain & Date isolated & Source & $\begin{array}{l}\text { Method } \\
\text { of isolation* }\end{array}$ \\
\hline $66-5 \mathrm{~B}$ & September I 965 & $\begin{array}{l}\text { Ceramium rubrum filament, } \\
\text { Newport, Rhode Island }\end{array}$ & IA \\
\hline $66-6 A$ & July I965 & $\begin{array}{l}\text { Polysiphonia sp. filament, } \\
\text { Newport, Rhode Island }\end{array}$ & I \\
\hline $66-8 \mathrm{~A}$ & September 1965 & $\begin{array}{l}\text { Ceramium rubrum filament, } \\
\text { Newport, Rhode Island }\end{array}$ & IA \\
\hline $68-30 \mathrm{~A}$ & \multicolumn{3}{|c|}{$\begin{array}{l}\text { H. marina strain wH } 49 \text { of Dr H. Vishniac. Received from } \\
\text { Dr S. Goldstein as Dermocystidium sp. Isolated from coastal } \\
\text { waters near Wood's Hole, Massachusetts. ATCC } 16323 \text {. }\end{array}$} \\
\hline $68-31 \mathrm{~A}$ & \multicolumn{3}{|c|}{$\begin{array}{l}\text { H. marina strain LIS } 37 \text { of Dr S. Goldstein. Received from } \\
\text { American Type Culture Collection as Dermocystidium sp. Isolated } \\
\text { from coastal waters near Bayville, New York. ATCC I } 6324 \text {. }\end{array}$} \\
\hline $69-$ I A & May 1969 & $\begin{array}{l}\text { Endocladia sp. filament, } \\
\text { Moss Beach, California }\end{array}$ & IA \\
\hline $69-2 \mathrm{~A}$ & June 1969 & $\begin{array}{l}\text { Endocladia sp. filament, } \\
\text { Moss Beach, California }\end{array}$ & I \\
\hline $69-3 \mathrm{~A}$ & June 1969 & $\begin{array}{l}\text { Phyllospadix sp. blade, } \\
\text { Moss Beach, California }\end{array}$ & IA \\
\hline $69-4 A$ & June 1969 & $\begin{array}{l}\text { Polysiphonia sp. filament, } \\
\text { Moss Beach, California }\end{array}$ & I \\
\hline $69-5 \mathrm{~A}$ & May 1969 & $\begin{array}{l}\text { Gelidium sp. filament, } \\
\text { Moss Beach, California }\end{array}$ & I \\
\hline $69-6 A$ & June 1969 & $\begin{array}{l}\text { Sea water, } \\
\text { Moss Beach, California }\end{array}$ & II \\
\hline
\end{tabular}

Isolation and maintenance of organisms. Strains of Hyalochlorella marina were isolated as described by Poyton (1970). The method used is indicated in Table I. Clones of each isolate were established from daughter organisms (autospores) either by successive transfer of single colonies or by micromanipulation using a de Fronbrume micromanipulator. Stock cultures were maintained on moist gelatin hydrolysatedextrose-yeast extract (GDY) agar slants composed of $(\% \mathrm{w} / \mathrm{v})$ : gelatin hydrolysate (enzymic, Nutritional Biochemicals Co.) O.I; dextrose, O.I; yeast extract (Difco), $0.0 \mathrm{I}$; Noble agar (Difco), I.2; sea water adjusted to a salinity of $33 \%$ with a Beckman RB3 Solu-Bridge. Slants were incubated at 20 to $22^{\circ}$ and transferred every 5 to 6 weeks. Prototheca strains were cloned and incubated as described above. Stock cultures were maintained on slants of malt extract agar (Difco) and transferred every 6 to 8 weeks.

On receipt of Chlorella sp. strain 820 it was cloned as above and maintained under the same conditions as Hyalochlorella, except that it was incubated under continuous light of low intensity (4000 lux). Spontaneous colourless mutants were isolated by 
inoculating a GDY agar plate with a dense suspension of Chlorella sp. and incubating it in the dark. After I week, occasional large creamy white colonies were observed. These were streaked on GDY plates and incubated in continuous light (4000 lux) to insure that they were not reversible mutants. Each mutant was cloned and maintained under the same conditions as Hyalochlorella.

Growth conditions. Liquid cultures were incubated at $20^{\circ}$ on a rotary shaker at $200 \mathrm{rev} . / \mathrm{min}$. in either $125 \mathrm{ml}$. Erlenmeyer flasks, with sidearms which fit a KlettSummerson colorimeter, containing $25 \mathrm{ml}$. medium or in $20 \mathrm{ml}$. screw-cap test tubes containing 5 to $10 \mathrm{ml}$. medium. Turbidity in the culture flasks was measured with a Klett-Summerson colorimeter using a blue (c. $420 \mathrm{~nm}$.) filter. Standard curves relating dry weight to Klett units were established for representative strains and turbidity determinations were taken on or corrected to the linear portion of these curves.

Anaerobic incubations were done in a Torbal jar containing $94 \%(\mathrm{v} / \mathrm{v}) \mathrm{H}_{2}$ and $6 \%(\mathrm{v} / \mathrm{v}) \mathrm{CO}_{2}$; residual oxygen was removed by including platinum-coated alumina pellets (Heller, 1954). Two methylene blue indicators of anaerobiosis were used. One was made up as described by Meynell \& Meynell (1965) and the other was an Anaerobic Indicator (Baltimore Biological Laboratory). Both were generally colourless within $6 \mathrm{~h}$. after adding the gas mixture. The test medium was GDY with $0.6 \%(\mathrm{w} / \mathrm{v})$ dextrose.

Cell cycle analysis. The relationships between growth and nuclear and cell division were studied in two ways. In the first, the growth of single organisms was followed microscopically in a microperfusion chamber (Poyton \& Branton, 1970) set up for either gas or liquid perfusion. For liquid perfusion, medium was aerated by sparging with sterile air just before being fed through the chamber at I $\mathrm{ml}$./min. Organisms were kept stationary by the Cellophane-strip technique previously referred to by Poyton \& Branton (1970). For gas perfusion, the top coverslip of the chamber was coated with a very thin layer of GDY agar as described by Skerman (1967) and inoculated. Humidified sterile air at $20^{\circ}$ was passed through the chamber.

For the second approach, distributions of organism volumes were compared with distributions of the numbers of nuclei per organism. Volumes were determined with a Coulter Counter model B (Coulter Electronics, Inc., Hialeah, Florida) equipped with a $100 \mu \mathrm{m}$. aperture and a Size Distribution Plotter model J. Paper mulberry pollen was used for volume calibrations; all counts were corrected for background counts in the diluent. Nuclei were stained by the Feulgen method as follows. Samples from a culture growing exponentially in GDY medium were centrifuged at $2000 \mathrm{~g}$ for Io min. to give a pellet of 0.005 to $0.02 \mathrm{ml}$. The organisms were washed once with distilled water, fixed in Carnoy's acetic acid-alcohol for Io min. (Bakerspigel, 1957) and then taken through the procedure of Tamiya, Morimura, Yokota \& Kunieda (I96I) or Bakerspigel (1957). The Schiff reagent was made according to Leuchtenberger (1958). Fixed organisms were hydrolysed in I $\mathrm{N}-\mathrm{HCl}$ at $60^{\circ}$ for $5,10,15$ and $20 \mathrm{~min}$. Optimal staining occurred after $15 \mathrm{~min}$. hydrolysis with the method of Tamiya et al. (196I) and after Io min. hydrolysis with the method of Bakerspigel (1957). At the end of the Feulgen staining procedure, organisms were mounted in acetocarmine as described by McIntosh (1954). To determine that nuclei were specifically stained by these procedures, two controls were routinely run: (I) organisms were exposed to $0.02 \%(\mathrm{w} / \mathrm{v})$ deoxyribonuclease as described by Jensen (1962) and (2) 
the $\mathrm{HCl}$ hydrolysis step was omitted. No stained bodies were seen in either control.

Variation in number of autospores. The number of daughters (autospores) produced per mother (sporangium) was determined by observing microcolony development on slides coated with GDY agar (Skerman, 1967). Agar-coated slides were stored on the surface of a GDY agar Petri plate at $4^{\circ}$ until needed. They were inoculated at $20^{\circ}$ from early exponential phase GDY liquid cultures and incubated 40 to $48 \mathrm{~h}$. Sporangial bursts were scored microscopically either immediately after incubation or after storage at $4^{\circ}$ for no more than $\mathrm{Io}$ h.

Cytological observations. Cellulose in the wall was determined by the zinc-chloriodide method of Rawlins \& Takahashi (I952) and the IKI-H $\mathrm{SO}_{4}$ method of Johansen (1940). Pectic wall substances were detected by the Ruthenium Red method as described by Kessler \& Soeder (1962). Capsules and gelatinous matrices surrounding organisms were determined by negative staining in indian ink. Exponentially growing cells from a variety of media were tested.

The presence and localization of intracellular starch was determined by making wet mounts of both fixed and unfixed organisms in IKI. Hyalochlorella and spontaneous colourless mutants of Chlorella were fixed in Carnoy's acetic acid-alcohol; Prototheca was fixed in $10 \%(\mathrm{v} / \mathrm{v})$ formalin. In all cases, fixed and unfixed organisms gave similar results. Intracellular lipid granules were stained with Sudan Black as described by Burdon (1946). Organisms were taken from exponential and stationary phase cultures grown on GDY agar and GDY agar plus $2 \%(w / v)$ glucose.

Vacuoles and refractile granules in exponentially growing cells were observed in wet mounts by phase contrast microscopy.

Photomicrography. All photomicrographs except Pl. I, fig. 2 were taken on Adox KB I4 $35 \mathrm{~mm}$. film through a Leitz Ortholux microscope equipped with apochromatic phase contrast objectives and a Heine condenser. For Pl. I, fig. 2, Ultropak achromatic objectives with ring condensers were used and dark-field reflected light illumination was provided by an Ultropak illuminator.

Production of extracellular enzymes. Extracellular enzymes were sought by replica plating (Lederberg \& Lederberg, I952) as described by Stanier, Palleroni \& Doudoroff (I966). A set of master plates were prepared on GDY medium rehydrated with tap water for Prototheca strains and with sea water for Hyalochlorella strains and colourless mutants of Chlorella. They were patched with I 5 strains and incubated for I week. One master plate served to print 12 test plates.

Extracellular gelatinase production was determined as described by Skerman (I967): gelatin, $5 \%(\mathrm{w} / \mathrm{v})$, was added to yeast extract (Difco), $0.5 \%(\mathrm{w} / \mathrm{v}) ; \mathrm{K}_{2} \mathrm{HPO}_{4}$, $0 . \mathrm{I} \%(\mathrm{w} / \mathrm{v}) ; \mathrm{MgSO}_{4} .7 \mathrm{H}_{2} \mathrm{O}, 0.02 \%(\mathrm{w} / \mathrm{v})$; Ionagar (Oxoid), $\mathrm{I} \cdot 0 \%$ (w/v); tap water or sea water. Each strain was replicated in duplicate. One set was flooded with acidic mercuric chloride after 5 days and the other after Io days of incubation. Only strains which showed a clear zone extending beyond the limits of growth were scored as positive. Gelatin liquefaction was assessed in $12.8 \%(\mathrm{w} / \mathrm{v})$ Difco nutrient gelatin. The stab was examined for liquefaction periodically over 2 weeks.

Extracellular lipase was determined by the method of Sierra (1957). After sterilization, the peptone medium was supplemented with $\mathrm{I} \%(\mathrm{w} / \mathrm{v})$ polyoxyethylene $(20)$ sorbitan mono-oleate (Tween 80 ) and the $\mathrm{pH}$ was adjusted to $7 \cdot 2$. Observations were made over 8 days. 
Starch hydrolysis was determined in agar and liquid GDY containing $0.2 \%(\mathrm{w} / \mathrm{v})$ soluble starch in place of dextrose. After 8 days, the plates were flooded with Lugol's iodine solution (Society of American Bacteriologists, 1957) and observed for colourless areas beneath and around the patches of growth. Starch hydrolysis in liquid medium was determined by adding one drop of Lugol's iodine solution to small aliquots withdrawn after 5 and Io days and comparing the colour with an uninoculated medium control.

Alginate digestion was determined by a modification of the method described by Skerman (1967). Agar plates of two layers were made: $1 \cdot 0 \%(\mathrm{w} / \mathrm{v})$ sodium alginate (Sigma) and $\mathrm{I} \cdot 6 \%(\mathrm{w} / \mathrm{v})$ Noble agar (Difco) on top of GDY agar minus dextrose (GY agar), both rehydrated with tap water or sea water. Plates were examined over I 4 days. Tap water plates were flooded with $\mathrm{I} \%$ (w/v) $\mathrm{CaCl}_{2} \cdot 2 \mathrm{H}_{2} \mathrm{O}$ and scored for a clear zone around the colonies. Sea water plates were scored for clarification directly.

The hydrolysis of agar was determined by growing organisms on the surface of GY agar. Evaporation from these plates was minimized by incubating them in plastic bags. Plates were observed over 20 days for agar softening around each patch of growth.

Growth in complex media. Growth and colony morphology were assessed on a variety of complex media rehydrated with distilled water or sea water. These were: $3.0 \%(\mathrm{w} / \mathrm{v})$ Difco fluid thioglycollate medium with $1.4 \%(\mathrm{w} / \mathrm{v})$ Difco Noble agar; $4.0 \%$ (w/v) Difco Emerson YpSs agar; $2.3 \%$ (w/v) Difco nutrient agar; GDY agar supplemented with $2 \cdot 0 \%(\mathrm{w} / \mathrm{v})$ dextrose $; 2 \cdot 0 \%(\mathrm{w} / \mathrm{v})$ Difco peptone supplemented with $0.2 \%(\mathrm{w} / \mathrm{v})$ dextrose plus $\mathrm{I} \cdot 2 \%$ (w/v) Difco Noble agar; and $3 \%(\mathrm{w} / \mathrm{v})$ Difco malt extract plus $\mathrm{I} \cdot 2 \%$ (w/v) Difco Noble agar. Growth was recorded after 7 and Io days as + (good growth), \pm (poor growth but better than control plate of GDY agar without dextrose), - (no more growth than on control plate).

Miscellaneous tests. Catalase production was determined by the evolution of $\mathrm{O}_{2}$ bubbles from cell smears flooded with $3 \%$ (v/v) $\mathrm{H}_{2} \mathrm{O}_{2}$.

Clumping of newly discharged autospores was scored directly by microscopic observation and indirectly by scoring for cellular clumps in agitated GDY liquid medium and for a pellicle in unagitated GDY medium. Both tests were run on organisms incubated in $10 \mathrm{ml}$. medium in $20 \mathrm{ml}$. test tubes. In agitated medium, large clumps of organisms resulted from the aggregation of clumped autospores around air bubbles. The pellicle formed in unagitated medium resulted partly from this aggregation and partly from the surface tension properties of autospore clumps. The pellicle generally represented 5 to $10 \%$ of the total count. The remaining 90 to $95 \%$ of the organisms formed a pellet. All cultures were scored after 4 to 6 days.

Wall strength was arbitrarily measured as susceptibility or resistance to sonication and freeze-thawing. Exponentially growing organisms were used in both tests. They were washed once with distilled water, centrifuged at $4^{\circ}$ for $10 \mathrm{~min}$. at $2000 \mathrm{~g}$, resuspended in distilled water and treated for $10 \mathrm{~min}$. at $0^{\circ}$ with a $\mathrm{IO} \mathrm{kc}$. Ratheon sonic oscillator. For freeze-thawing, the organisms were washed once with distilled water, collected by centrifugation and rapidly frozen to $-20^{\circ}$. After $24 \mathrm{~h}$. they were rapidly thawed to $37^{\circ}$. Wall breakage by both methods was assessed microscopically. 


\section{RESULTS}

Morphological observations and developmental cycle analysis

Hyalochlorella marina individuals were colourless and produced creamy, yeast-like colonies on agar medium. On GDY agar the colonies were convex and generally smooth-margined (Pl. I, fig. I) under a dissecting microscope. However, in some strains, older colonies (I 2 to 20 days) developed 'watery' edges (P1. I, fig. 3) which resulted from the degradation of peripherally located organisms. As the colony grew older, the 'watery' region proceeded toward the colony centre, and at the end of about 25 days the colony was devoid of spherical cells. Whether this degradation was due to lysis or to synctium formation is uncertain, but the presence of walls radiating out from the colony centre into the 'watery' region seems to rule out lysis. Attempts to subculture pieces of the 'watery' edge were unsuccessful. In all strains, colonies with irregular haloes (Pl. I, fig. 2) were observed, but with an incidence of less than $0.5 \%$. These haloes were formed by motile preautospores which migrated from the colony and subsequently became encased by a wall. This will be discussed in more detail below.

One of the difficulties in the taxonomy of simple chlorococcalean algae such as Chlorella and Prototheca is their paucity of distinguishing morphological characteristics. The two characteristics which have been used in previous considerations of Prototheca are size and shape (Pringsheim, I963; Cooke, I968b). Often, in giving size, authors have failed to specify which developmental stage was measured. Since sporangial size is directly related to the number of autospores produced and since the developmental stages between the autospore and sporangium can be only temporarily distinguished, the only stage for which size determinations were felt valuable in this study was the newly discharged autospore. Measurements of 500 newly discharged autospores of each strain growing exponentially on GDY liquid and agar medium showed a range in diameter of 4 to $6.5 \mu \mathrm{m}$. and a mean diameter of $5.5 \mu \mathrm{m}$. Immature sporangium diameters varied from 7 to $25 \mu \mathrm{m}$.; the smaller sporangia produced 2 autospores and the larger sporangia up to 128 autospores. The cell shape is spherical and occasionally ovoidal.

The developmental cycle discussed below is based mostly on studies with strain 66-6A, the type culture, and strains 66-5B, 66-8 A, 68-30 A and 68-3I A. Asexual reproduction took place by autospore formation. Following emergence of the uninucleate autospore, the developmental cycle (Pl. 2 \& Fig. I) involved the immediate formation of a centric or eccentric vacuole followed by an increase in size with a concomitant increase in the number of nuclei by nuclear division. The immature sporangium was spherical and multinucleate. Cytokinesis occurred by multiple fission during which the multinucleate protoplast of the immature sporangium was segmented simultaneously into uninucleate protoplasts. Segmentation begins by invagination of the peripheral protoplast and central vacuole membranes; both light microscope and electron microscope studies (Burr, unpublished work) showed the sporangial wall was not in any way involved. The uninucleate daughter protoplast (preautospore), devoid of a wall, was capable of motility similar to that of limax amoebae (P1. I, fig. I 2 to I4). As mentioned above, a small percentage of the colonies on each plate formed these motile preautospores. This percentage was greatly increased 
by incubating the plates at $4^{\circ}$ for $24 \mathrm{~h}$. or at low $\mathrm{O}_{2}$ tension $\left(2 \cdot \mathrm{I} \% \mathrm{v} / \mathrm{v} \mathrm{O}_{2}\right)$. These forms could also be seen by squashing an immature sporangium. Next in the developmental cycle, the preautospores formed a wall and were liberated from the sporangium by irregular lateral rupture of the sporangial wall. Autospores were sequentially discharged and were completely free from one another. In stationary phase cultures, occasionally not all of the autospores emerged from the sporangium and sometimes none emerged, giving rise to a structure which appeared to be a sorus of sporangia. Throughout the entire developmental cycle the wall (Pl. I, fig. IO) was smooth and thin. It did not thicken with age, but did become more apparent in mature sporangia because spaces developed between it and the enclosed autospores. At no stage did a capsule or gelatinous matrix surround the organism.

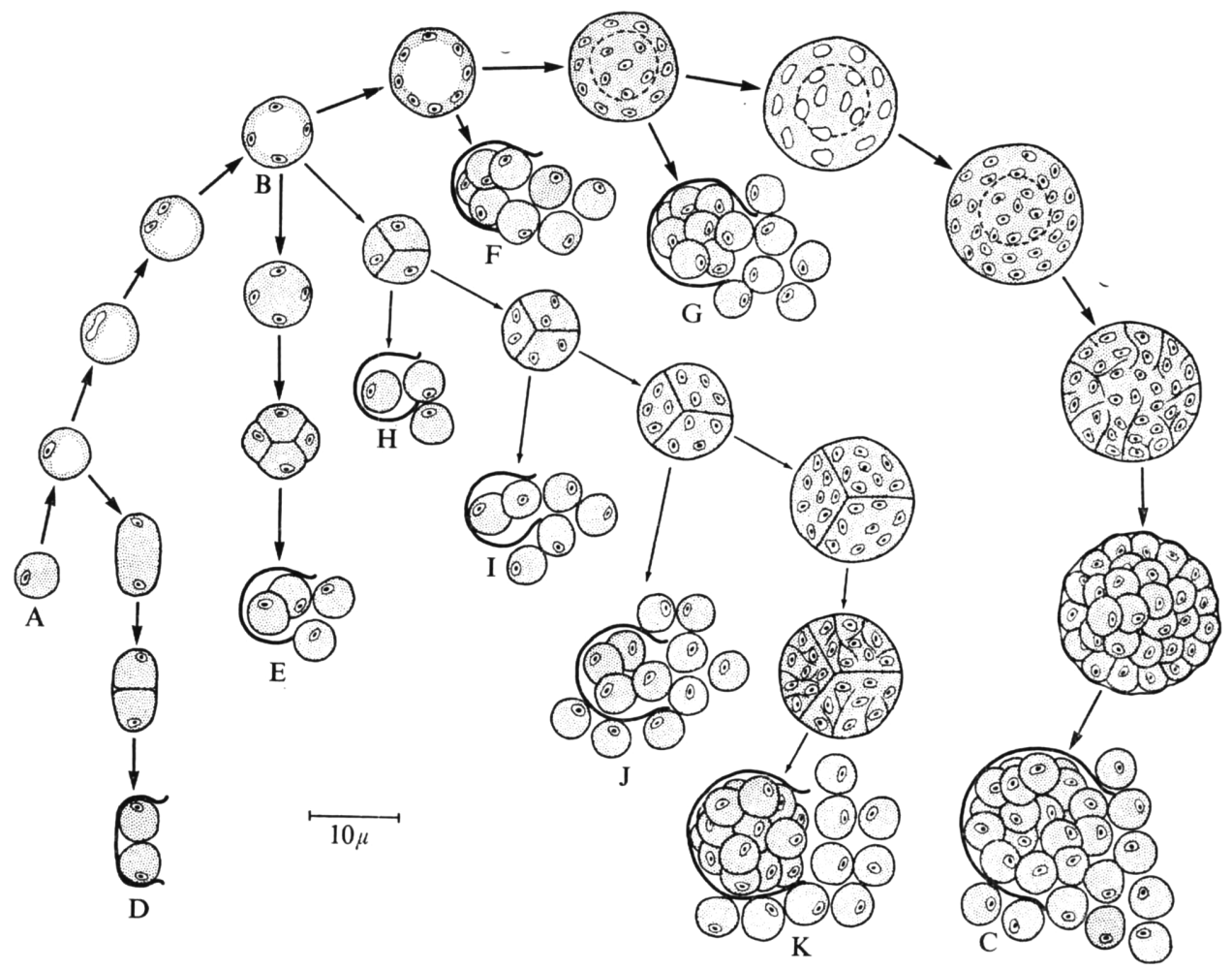

Fig. I. Semidiagrammatic drawing of the developmental cycle of Hyalochlorella marina. $\times 1300$.

Nuclear division. Preliminary microscopic observations indicated a correlation between nuclear number and size of organism. Organisms of immature sporangial size were never seen with only one or two nuclei and organisms of autospore size did not contain more than one nucleus. This suggested that nuclear division occurred concomitantly with growth rather than after the growth period, just before cytokinesis. To test this, distributions of size of individuals and numbers of nuclei per individual were compared for exponentially growing organisms (see Methods). If nuclei divided in step with increasing volume, one would expect the distribution curves to be superimposable, whereas if nuclear division occurred just before 
cytokinesis, one would expect the curves to be non-superimposable with a high narrow peak in nuclear distribution at one nucleus. The distribution curves were roughly superimposable (Fig. 2), indicating that nuclear division did indeed accompany growth.

Table 2. Spore number variation in Hyalochlorella marina

\begin{tabular}{|c|c|c|c|c|}
\hline \multirow{2}{*}{$\begin{array}{l}\text { Number of autospores } \\
\text { released }\end{array}$} & \multicolumn{4}{|c|}{$\begin{array}{c}\text { Number of mother cells } \\
\text { Strains }\end{array}$} \\
\hline & $66-5$ B & $66-6 \mathrm{~A}$ & $68-30 \mathrm{~A}$ & $68-3 \mathrm{IA}$ \\
\hline 2 & - & - & 3 & - \\
\hline 4 & - & - & I5 & 2 \\
\hline 6 & - & - & - & - \\
\hline 8 & 2 & 5 & 36 & 15 \\
\hline I2 & 4 & - & 25 & - \\
\hline I6 & 23 & 5 & 190 & 79 \\
\hline 24 & 19 & 5 & 22 & 4 \\
\hline 32 & 32 & 57 & 41 & 187 \\
\hline 48 & - & 6 & - & - \\
\hline 64 & I02 & 193 & 3 & 57 \\
\hline 128 & 36 & 62 & - & 6 \\
\hline $\begin{array}{l}\text { Numbers between } 2 \text { and I } 28 \\
\text { not specifically noted above } \\
\text { (incomplete cleavage) }\end{array}$ & 32 & 17 & 15 & $\circ$ \\
\hline Total number of mother cells & 250 & 350 & 350 & 350 \\
\hline $\begin{array}{l}\text { Percentage organisms giving } \\
\mathbf{2}^{n} \text { spores }\end{array}$ & 78 & 92 & $82 \cdot 3$ & $98 \cdot 8$ \\
\hline $\begin{array}{l}\text { Percentage organisms giving } \\
2^{n}-2^{n-2} \text { spores }\end{array}$ & $9 \cdot 2$ & $3 \cdot I$ & $13 \cdot 4$ & $\mathrm{I} \cdot 2$ \\
\hline $\begin{array}{l}\text { Percentage organisms giving } \\
\text { incomplete cleavage numbers }\end{array}$ & I2.8 & $4 \cdot 9$ & $4 \cdot 3$ & $\circ$ \\
\hline
\end{tabular}

Due to the small size of nuclei in Hyalochlorella it was rather difficult to determine its mode of nuclear division. Phase contrast microscopy of living organisms as well as observations of Feulgen acetocarmine stained organisms indicated that nuclear division took place by mitosis within the nuclear membrane. Enlarged nuclei lacking nucleoli were often seen in living immature sporangia (P1. 2, fig. I8). Stained organisms of all developmental stages possessed oblong and elongated nuclear division figures which stained most densely at their ends. The dense staining was presumably due to chromosomal material.

The relation of nuclear division to growth and cytokinesis is summarized in Fig. I. All of the nuclei within a multinucleate organism divided simultaneously. This is based on observations that the nuclear number per cell was usually an integral of $2^{n}$ and that when division figures were observed all of the nuclei in the cell possessed them.

Variation in spore number. Variation in the number of daughters produced per mother is a characteristic that most organisms which undergo asexual cytokinesis by simultaneous multiple fission have in common. Data for four representative strains of Hyalochlorella are given in Table 2. To eliminate the possibility that organisms in a cluster arose from more than one sporangium, only those bursts were scored which showed one sporangial wall and in which all of the daughters were approximately the same size (Pl. I, fig. 4 to 9). In exponentially growing cultures 
the number of daughters was usually $2^{n}$ where $n$ is $\mathrm{I}$ to 7 . Daughter numbers of $2^{n}-2^{n-2}(n=2$ to 6$)$ occurred with varying frequencies. This sequence was apparently initiated by the degeneration of one nucleus at the four nucleate stage (Fig. I B) and the division of the organism into three uninucleate protoplasts (Pl. I, fig. II). Subsequent growth and division occurred normally to give $2^{n}-2^{n-2}$ daughters (Fig. I B-H, B-I, B-J, B-K). Another source of variation from the $2^{n}$ number of daughters was incomplete cleavage of the sporangium. The clusters resulting from these sporangial bursts were easily recognized by the presence of daughters of variable size. While most of the daughters were of normal volume, some were twice this volume. Daughter numbers of $14,26,28$ and 56 were often recorded. The frequency of incomplete cleavage in each strain varied but was usually less than $5 \%$. It was lowest in exponential phase cultures and increased in the stationary phase.

In view of the wide variation in number of daughters and its dependence on culture conditions (Goldstein \& Moriber, 1966; R. O. Poyton, unpublished), the number of autospores produced per sporangium has been ruled out as a means of distinguishing species within the genus Hyalochlorella.

Physiological and biological characteristics. Initial comparisons of Hyalochlorella and Prototheca indicated that the two genera had similar morphologies and identical developmental cycles but differed in the thickness of their walls, the presence of a large centric or eccentric vacuole in Hyalochlorella and the clumping of autospores during and after discharge in Prototheca. To seek more distinguishing characteristics, the tests in Table 3 were made on several strains of both genera. With the exception of slight extracellular amylase activity for strain 69-3 and variable growth on thioglycollate agar, there was no variation among the II strains of $H$. marina. Among the 17 strains of Prototheca there was a great deal of variation in colony morphology on thioglycollate agar and in the thickness of the pellicle formed on GDY medium. Otherwise, except for morphological differences and differences in size which have been previously noted (Tubaki \& Soneda, I959; Pringsheim, I963; Cooke, I968 b), there was little variation. The three colourless Chlorella strains studied showed no variation at all.

Characteristics of Hyalochlorella, Prototheca, Chlorella and colourless mutants of Chlorella are listed in Table 4. These organisms have in common similar shapes and size, cytokinesis via multiple fission, and walls of high tensile strength. In each genus, the number of autospores produced per sporangium varies, usually being an integral of $2^{n}$. An infrequent developmental pathway gives $2^{n}-2^{n-2}$ autospores per sporangium. As described above, this occurs in Hyalochlorella due to the degeneration of one nucleus of a tetranucleate cell (Fig. I, A-B-K). A similar developmental sequence has been inferred from counts of the number of daughter cells of P. zopfii in which it occurs with a frequency of less than $5 \%$ (R. O. Poyton, unpublished work). Although this developmental pathway is not well documented in Chlorella, there are data listing autospore number per sporangium in which numbers in the series $2^{n}-2^{n-2}$ do occur (Murakami, Morimura \& Takamiya, I963; Kuhl \& Lorenzen, 1964). Perhaps some of the tetrads of spores commonly figured for Chlorella (e.g. Resigl, 1964) are actually triads like that pictured in Pl. I, fig. II.

The existence of motile preautospores in Hyalochlorella is at the moment considered a useful characteristic for differentiating it from Prototheca. Similar structures have also been reported for Chlorella (Rětovský \& Klášterská, 196I). Perhaps the reason 
why Prototheca does not exhibit these forms is that the pectinaceous matrix in which autospores and preautospores lie inhibits cell movement. Another possible explanation is that the wall of Prototheca is more resistant to breakage than that of Hyalochlorella and thus prevents the emergence of preautospores. The sporangial wall of Prototheca is 0.1 to $0.2 \mu \mathrm{m}$. thick (Lloyd \& Turner, I968), about three times that of Hyalochlorella walls. Differences in wall composition may also be implicated.

The pectinaceous ground substance surrounding autospores in the mature

Table 4. Some characteristics of Chlorella and its colourless counterparts*

\begin{tabular}{|c|c|c|c|c|}
\hline \multirow{2}{*}{$\begin{array}{l}\text { Cell morphology: } \\
\text { Shape }\end{array}$} & Hyalochlorella & Prototheca & $\begin{array}{l}\text { Chlorella } \\
\text { (colourless } \\
\text { mutants) }\end{array}$ & Chlorella \\
\hline & Spherical & $\begin{array}{l}\text { Spherical, } \\
\text { ovoidal, } \\
\text { ellipsoidal }\end{array}$ & Spherical & $\begin{array}{r}\text { Spherical } \\
\text { ovoidal }\end{array}$ \\
\hline Autospore size & $4^{-6.5 \mu \mathrm{m}}$ & $2-10 \mu \mathrm{m}$ & $2-4 \mu \mathrm{m}$. & $2-8 \mu \mathrm{m}$ \\
\hline Central vacuole & + & - & - & $\mathrm{v} \dagger$ \\
\hline Refractile granules & - & + & + & $\mathbf{v}$ \\
\hline \multicolumn{5}{|l|}{ Development: } \\
\hline Motile preautospores & + & - & + & + \\
\hline Autospores clumped on discharge & - & + & + & $\mathrm{v}$ \\
\hline Variable autospore number & + & + & + & + \\
\hline Autospore numbers of $2^{n}-2^{n-2}$ & + & + & + & + \\
\hline $\begin{array}{l}\text { Pectinaceous ground substance in } \\
\text { mature sporangium }\end{array}$ & - & + & - & - \\
\hline Pellicle formation & - & + & - & - \\
\hline \multicolumn{5}{|l|}{ Storage products: } \\
\hline Fat & + & - & - & $?$ \\
\hline Carbohydrate & + & + & + & + \\
\hline \multicolumn{5}{|l|}{ Intracellular carbohydrate storage: } \\
\hline Pyrenoid & - & - & - & + \\
\hline Granules & - & + & - & - \\
\hline Dispersed & + & - & + & - \\
\hline Anaerobic growth & - & - & - & - \\
\hline Catalase activity & + & + & + & + \\
\hline \multicolumn{5}{|l|}{ Walls: } \\
\hline Resistant to freeze-thaw & + & + & + & + \\
\hline Resistant to sonification & + & + & + & + \\
\hline Contain cellulose & - & - & - & + \\
\hline Contain pectin & + & - & - & $\mathrm{v}$ \\
\hline \multicolumn{5}{|l|}{ Growth on: } \\
\hline YpSs agar & - & + & + & $?$ \\
\hline Malt agar & - & + & + & $?$ \\
\hline \multicolumn{5}{|l|}{ Extracellular enzymes: } \\
\hline Amylase & - & - & - & $?$ \\
\hline Gelatinase & - & - & - & $\dot{v}$ \\
\hline Agarase & - & - & - & ? \\
\hline Lipase & + & - & - & ? \\
\hline Alginase & - & - & - & ? \\
\hline
\end{tabular}

* Data for Hyalochlorella, Prototheca and colourless mutants of Chlorella come from Table 3. Data for Chlorella were compiled from Fritsch, 1948; Northcote, Goulding \& Horne, I958; Murakami, Morimura \& Takamiya, 1963; Soeder, 1963; Kuhl \& Lorenzen, 1964. $\dagger \mathrm{v}=$ Variable. 
sporangium is another useful means of distinguishing Hyalochlorella from Prototheca. It was first noticed in Prototheca by electron microscopy (Menke \& Fricke, 1962) and in my study it was demonstrated with Ruthenium Red. Light and electron microscopy (F. Burr, unpublished work) show no such matrix in Hyalochlorella. It seems very likely that the clumping of newly discharged autospores in Prototheca can be accounted for by the presence of this matrix around cells before, during and immediately after discharge.

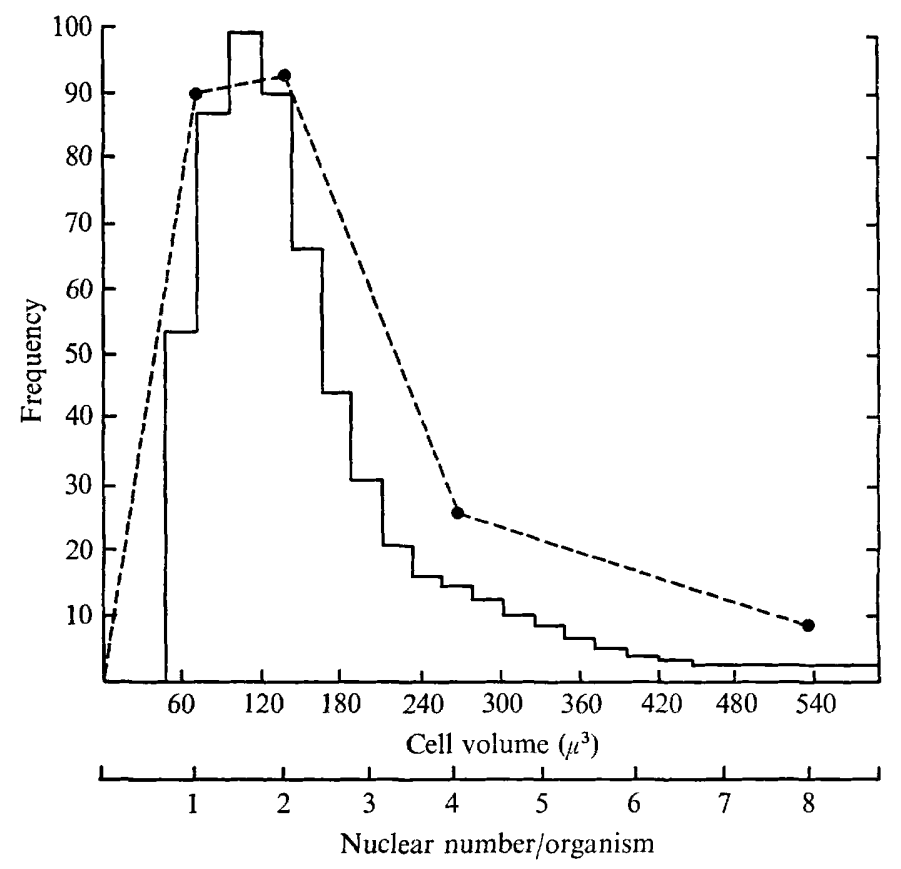

Fig. 2. Distributions of sizes and nuclear numbers for Hyalochlorella marina. Strain 66-6A was grown to mid-exponential phase on GDY medium supplemented with $0.6 \%$ gelatin hydrolysate. Size (-) was determined for organisms suspended in sea water of salinity $33 \%$. The total number of organisms measured was 15,180 . Nuclear number/organism (0) - - was determined for a total of 300 . Strains $66-5 \mathrm{~B}, 68-30 \mathrm{~A}$ and $68-3 \mathrm{I}$ a gave similar curves.

Hyalochlorella also differs from Prototheca in its lack of refractile granules (presumably carbohydrate), its possession of a large vacuole and an extracellular lipase, its inability to grow on YpSs agar, malt agar and GDY medium rehydrated with tap water, and its accumulation of fat as well as carbohydrate. Fats are collected as large droplets in both exponential and stationary phase cultures of Hyalochlorella; polysaccharides are dispersed throughout the cytoplasm. The amount stored per organism increases greatly when the glucose in the growth medium is raised to 2 to $3 \%(\mathrm{w} / \mathrm{v})$. The exact nature of the polysaccharides is at the moment uncertain; the red-brown coloration given with IKI is quite different from the blue-black colour given by starch, which suggests that the polysaccharide products in Hyalochlorella, Prototheca and the colourless strains of Chlorella are of relatively short chain length. 
Requirements for a marine environment. All strains of Hyalochlorella so far isolated fit the criteria defining a marine bacterium (MacLeod, 1965). Unlike the species of Prototheca listed above, Hyalochlorella marina grew only on isolation plates rehydrated with sea water.

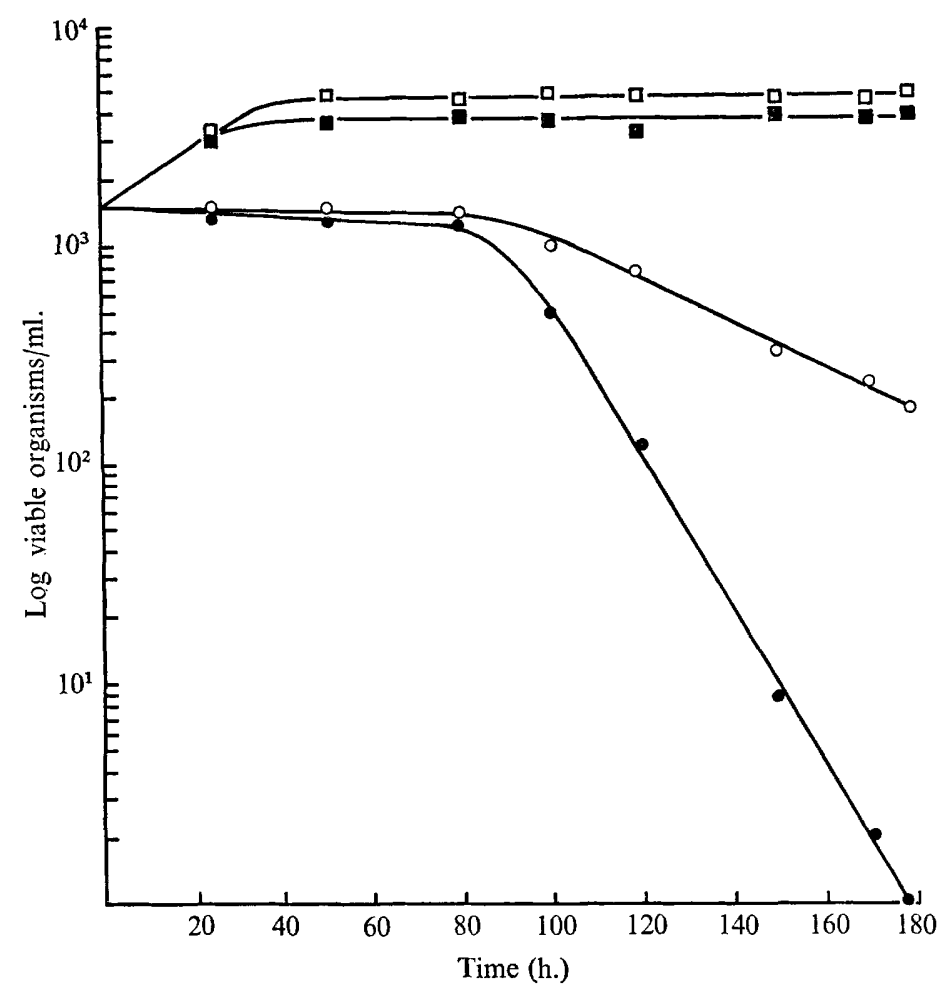

Fig. 3. Kinetics of death of Hyalochlorella marina 66-6A in distilled water media. Organisms were incubated at $20^{\circ}$ in distilled water (-) GDY medium rehydrated with distilled water $(\mathrm{O}-\mathrm{O})$, sea water (--) and GDY medium rehydrated with sea water $(\square-\square)$. Samples were taken at various time intervals and plated on GDY medium for viable count determinations. Similar curves were obtained for strains $66-8 \mathrm{~A}, 68-30 \mathrm{~A}$ and 68-3I A.

The dry weight yield in GDY medium with $0.6 \%(\mathrm{w} / \mathrm{v})$ gelatin hydrolysate increased linearly from $O$ with sea water salinities between 0 to $23 \%$, was constant in the range 23 to $40 \%$ and decreased in salinities exceeding $40 \%$. Swelling and death occurred in media of low osmotic pressure. Populations incubated in distilled water at $20^{\circ}$ usually exhibited a diphasic death curve (Fig. 3). For strain 66-6A the first phase lasted for 80 to $90 \mathrm{~h}$. and practically no loss of viability occurred. In the second phase the death rate was $0.12 \mathrm{~h}^{-1}$. The death rate was two to three times less for organisms in GDY medium. Control cultures incubated in sea water or GDY medium rehydrated with sea water increased in viable count to a value which remained constant. No evidence for cell-wall thickening as a means of resistance to high or low osmotic pressure has ever been obtained. 


\section{DISCUSSION}

The taxonomic position of Hyalochlorella is subject to the same consideration as its analogue Prototheca. Generally, Prototheca has been considered to be a nonpigmented counterpart of Chlorella (West, I9I6; Fritsch, I948). However, some authors have favoured a taxonomic position closer to the fungi (Krüger, I894; Saccardo \& Traverso, I9II; Tubaki \& Soneda, 1959). Lloyd \& Turner (I968) concluded from its wall composition that it probably is not an achloric counterpart of Chlorella. Attempts to relate Prototheca to the fungi have relied almost entirely on the morphology of the mature sporangium, which resembles the asci of many ascomycetes and the spherules of some fungi of uncertain affinities. In these attempts, development and sporogenesis have been largely ignored.

In ascomycetes, ascospore formation is preceded by conjugation and takes place by free cell formation. Spore initials are formed within the ascal cytoplasm and out of contact with the mother cell plasmalemma (Madelin, 1966). The formation of sporangia in Prototheca and Hyalochlorella is not preceded by conjugation and the mother cell plasmalemma plays an active role during spore delimitation, eventually becoming part of the daughter cell plasmalemma. In view of these developmental differences it is unlikely that Prototheca and Hyalochlorella are close relatives of the ascomycetes.

One fungus which has a mode of spore formation similar to that of Hyalochlorella is Coccidioides, a dermatophyte of uncertain affinities. The endospore and spherule of Coccidioides are analogous to the autospore and mature sporangium of Hyalochlorella. Although sporogenesis in both genera occurs by multiple fission (Tarbet, Wright \& Newcomer, 1952), Coccidioides differs from Hyalochlorella in the active role which the sporangial wall plays in sporogenesis (O'Hern \& Henry, I956; Breslau, Hensley \& Erickson, I96I), the uneven thickening of the newly discharged endospore wall (Moore, 1965), and the production of a mycelial culture phase (Baker, Mrak \& Smith, I943). Moreover, during endospore formation in Coccidioides the mother cell wall is contiguous with the daughter wall and on spore discharge no sporangial wall is left behind. In Hyalochlorella the mother cell wall is not contiguous with the daughter cell wall and is left behind intact on spore discharge. These differences seem sufficient to rule out any taxonomic relatedness of these two genera.

A preliminary study of strains 68-30 A and 68-3I A lead Goldstein \& Moriber (I966) to characterize them tentatively as marine fungi of the poorly defined genus Dermocystidium. This has aroused interest in the relationship between these strains and the other members of the genus, for they would represent the only members of the genus whose complete development has been studied in pure axenic culture. Goldstein \& Moriber's (1966) assignation of these strains to the genus Dermocystidium was based on their general morphology and possession of a refringent vacuolar inclusion (vacuoplast), considered to be an important feature of the genus Dermocystidium (Perez, 1907; Mackin, 1962). The paucity of morphological features makes it extremely difficult to distinguish these strains from some other micro-organisms. Therefore a heavy reliance must be placed on developmental and physiological characteristics. Perkins (I969) has shown that vegetative cleavage in Dermocystidium marinum, the best characterized member of the genus, yields endospores with unevenly 
thickened walls by a series of events similar to those described above for Coccidioides. This developmental sequence is quite different from that reported by Goldstein \& Moriber (I966) for their strains. In the above study I have been unable to confirm two of the observations reported by Goldstein \& Moriber (I966). The vacuoplast is present only in stationary phase cultures and never in exponentially growing cells; when present, it occurs in less than $0.01 \%$ of the developing sporangia and can therefore hardly be considered typical. I have also been unable to confirm their inference that growth is accompanied by the periodic liberation of individuals from their walls by ecdysis. During the complete development of single individuals (PI. 2), the only stage during which a wall is shed is at autospore liberation.

The infrequent appearance of a vacuoplast, the possession of a mode of vegetative cleavage different from that found in Dermocystidium marinum, and the morphological and developmental similarities to Prototheca lead me to believe that these strains should not be placed in the genus Dermocystidium and to erect the new algal genus Hyalochlorella.

On the basis of morphology and development, Hyalochlorella is a colourless counterpart of the alga Chlorella and analogous to Prototheca. In addition to its mode of sporogenesis, features it has in common with Chlorella are motile preautospores, variable numbers of autospores, and walls of high tensile strength. Hyalochlorella differs from Prototheca in discharging autospores sequentially and separately rather than as a clump, in lacking a pectinaceous ground substances in the mature sporangium, in possessing a large vacuole in all developmental stages except for the autospore and mature sporangium, and in the wall reaction with Ruthenium Red. All Hyalochlorella marina strains give a pectin positive reaction of variable intensity, whereas all strains of Prototheca give a negative reaction. Some Chlorella species give a positive Ruthenium Red reaction of varying intensity and some a negative reaction (Kessler \& Soeder, 1962). Possibly, Prototheca is more closely related to the Ruthenium Red negative strains and Hyalochlorella to the Ruthenium Red positive strains.

Hyachlorella marina gen. et sp.nov.

Cellulae sine colore, in agaro nutriente colonias cremias fermentoideasque, marginibus plerumque levibus, efficientes. Cellulae vegetativae iuvenes (autosporea) uninucleatae, membranam tenuem habentes, sphericae ad ovoideas, 4 ad $6.5 \mu \mathrm{m}$. diam. Reproductio asexualis per formationem autosporarum effecta. Crescentia formationem vacuolae eccentricae magnae implicat, deinde cellula crescit, simul nucleus se dividit. Sporangium immaturum sphericum, 7 ad $25 \mu \mathrm{m}$. diam., multinucleatum. Cytokinesis per fissionem multiplicem ad 2, 4, 8, I6, 32, 64, I 28 vel 3, 6, I 2, 24, 48 autosporas uninucleatas in omni sporangio formandas effecta. Autosporae ruptura laterali membranae sporangii liberatae. Protoplasti mobiles emergentes interdum observati. Omnes autosporae in culturis in periodo crescentiae immobili interdum e sporangio non emergunt; aliquando nullae autosporae emergunt, ut sorum sporangiorum efficiatur. Membrana cellulae levis tenuisque, senescens non spissescens. Matrix gelatinosa membranam circumdans nulla. Cellulae in cultura liquida non se cohaerentes. Reproductio sexualis non observata.

The author expresses his appreciation to Dr D. Branton, Dr M. S. Fuller and Dr J. A. West for their interest and helpful suggestions during this study. He would 
also like to thank Dr C. B. van Niel and Dr S. Goldstein for the strains which they contributed, Dr D. Branton for the use of his Leitz Ortholux microscope, Dr L. Packer for the use of his Coulter Counter and Dr H. Croasdale for the Latin translation This work was supported by a N.A.S.A. Grant (NsG(T)-I I7-2).

\section{REFERENCES}

Ashford, B. K., Ciferri, R. \& Dalmau, L. M. (1930). A new species of Prototheca and a variety of the same isolated from the human intestine. Archiv für Protistenkunde 7o, 619-638.

Baker, E. E., Mrak, E. M. \& SMITH, C. E. (I943). The morphology, taxonomy, and distribution of Coccidioides immitis Rixford and Gilchrist I896. Farlowia I, I99-244.

BAKERSPIGel A., (1957). The structure and mode of division of the nuclei in the yeast cells and mycelium of Blastomyces dermatitidis. Canadian Journal of Microbiology 3, 923-936.

BeIJERINCK, M. W. (1904). Chlorella variegata, ein bunter Mikrobe. Recueil des Travaux Botaniques Neerlandais $\mathbf{1}, \mathrm{I4}-27$.

Breslau, A. M., Hensley, T. J. \& Erickson, J. O. (196I). Electron microscopy of cultured spherules of Coccidioides immitis. Journal of Biophysical and Biochemical Cytology 9, 627-637.

Burdon, K. L. (1946). Fatty material in bacteria and fungi revealed by staining dried, fixed slide preparations. Journal of Bacteriology 52, 665-678.

ButLeR, E. E. (1954). Radiation-induced chlorophyll-less mutants of Chlorella. Science, New York I20, $274-275$.

COOKE, W. B. (1968a). Studies in the genus Prototheca. I. Literature review. Journal of the Elisha Mitchell Scientific Society 84, 213-216.

Сооке, W. B. (1968b). Studies in the genus Prototheca. II. Taxonomy. Journal of the Elisha Mitchell Scientific Society 84, 217-220.

Davies, R. R., Spencer, H. \& Wakelin, P. O. (1964). A case of human Protothecosis. Transactions of the Royal Society of Tropical Medicine and Hygiene 58, 448-45I.

Fritsch, F. E. (1948). The Structure and Reproduction of the Algae, vol. I. Cambridge University Press.

Fuller, M. S. \& Poyton, R. O. (1964). A new technique for the isolation of aquatic fungi. Bioscience I4, 45-46.

Goldstein, S. \& Moriber, L. (1966). Biology of a problematic marine fungus, Dermocystidium sp. I. Development and cytology. Archiv für Mikrobiologie 53, I-I I.

GranICK, S. (1948). Protoporphyrin 9 as a precursor of chlorophyll. Journal of Biological Chemistry 172, 717-727.

Heller, C. L. (I954). A simple method for producing anaerobiosis. Journal of Applied Bacteriology I7, 202.

JeNSEN, W. A. (1962). Botanical Histochemistry, p. 252. San Francisco: W. H. Freeman and Co.

Johansen, D. A. (1940). Plant Microtechnique. New York: McGraw-Hill.

KESSLER, E. \& SOEDER, C. J. (1962). Biochemical contributions to the taxonomy of the genus Chlorella. Nature, London 194, I096-1097.

KRÜGER, W. (I 894). Kurze Characteristik einiger niederer Organismen in Saftflüssen der Laubbäume. I. Ueber einen neuen Pilz-Typus, repräsentiert durch die Gattung Prototheca. (P. moriformis (sic) et $P$. zopfii). Hedwigia 33, 24I-25.

KuHL, A. \& LoRENZEN, H. (1964). Handling and culturing of Chlorella. In Methods in Cell Physiology, vol. 1, pp. 159-187. Edited by D. M. Prescott. New York: Academic Press.

LEDERBERG, J. \& LEDERBERG, E. M. (1952). Replica plating and indirect selection of bacterial mutants. Journal of Bacteriology 63, 399-406.

LEUCHTENBERGER, C. (1958). Quantitative determination of DNA in cells by Feulgen microspectrophotometry. In General Cytochemical Methods, vol. I, pp. 219-278. Edited by J. G. Danielli. New York: Academic Press.

Lloyd, D. \& Turner, G. (1968). The cell wall of Prototheca zopfi. Journal of General Microbiology 5o, $421-427$.

McINTOSH, D. L. (1954). A Feulgen-carmine technic for staining fungus chromosomes. StainTechnology 29, 29-3I. 
MACKIN, J. G. (I962). Oyster disease caused by Dermocystidium marinium and other micro-organisms in Louisiana. Publications of the Institute of Marine Sciences, University of Texas 7, 132-229.

MACLEOD, R. A. (1965). The question of the existence of specific marine bacteria. Bacteriological Reviews 29, 9-23.

Madelin, M. F. (1966). The genesis of spores of higher fungi. In The Fungus Spore. 18th Symposium of Colston Research Society, pp. 15-36. London: Butterworths.

Menke, W. \& Fricke, B. (1962). Einige Beobachtungen an Prototheca ciferri. Portugaliae Acta Biologica series A 6, 243-252.

Meynell, G. G. \& Meynell, E. (1965). Theory and Practice in Experimental Bacteriology, p. 74. Cambridge University Press.

Moore, R. T. (1965). The ultrastructure of fungal cells. In The Fungi, vol. I, pp. 95-I 8 . Edited by G. C. Ainsworth \& A. S. Sussman. New York: Academic Press.

Murakami, S., Morimura, Y. \& TaKamiYa, A. (I963). Electron microscopic studies along cellular life cycle of Chlorella ellipsoidea. In Studies on Microalgae and Photosynthetic Bacteria, pp. 65-83. Edited by J. Ashida. Tokyo: University of Tokyo Press.

Negroni, P. \& Blaisten, R. (I94I). Estudio morfologico y fisiologico de una nueva especie de Prototheca ciferrii n. sp., aislada de epidermis de papa. Mycopathologia et Mycologia Applicata 3, 94-104.

NorthCOte, D. H., Goulding, K. J. \& HoRne, R. W. (I958). The chemical composition and structure of the cell wall of Chlorella pyrenoidosa. Biochemical Journal 7o, 39I-397.

O'Hern, E. M. \& Henry, B. S. (1956). A cytological study of Coccidioides immitis by electron microscopy. Journal of Bacteriology 72, 632-645.

Perez, C. (1907). Dermocystis pusula, organisme nouveau de la peau des tritons. Compte Rendu des Séances de la Société de Biologie 63, 445-446.

Perkins, F. O. (1969). Ultrastructure of vegetative stages in Labyrinthomyxa marina ( $=$ Dermocystidium marinium), a commercially significant oyster pathogen. Journal of Invertebrate Pathology 13, 199-222.

Phaff, H. J., Yoneyama, M. \& Do Carmo-Sousa, L. (1964). A one-year, quantitative study of the yeast flora in a single slime flux of Ulmus carpinifolia Gled. Rivista di Patologia Vegetale, Padova serie III. 4, 485-497.

Poyton, R. O. (1970). The isolation and occurrence of Hyalochlorella marina. Journal of General Microbiology 62, 189-194.

Poyton, R. O. \& BRAnton, D. (1970). A multipurpose microperfusion chamber. Experimental Cell Research 60, 109-114.

Pringsheim, E. G. (1963). Farblose Algen. Stuttgart: Gustav Fischer Verlag.

Rawlins, T. E. \& Takahashi, W. N. (1952). Techniques of Plant Histochemistry and Virology. Millbrae, California: National Press.

RESIGL, H. (1964). Zur Systematik und Ökologie alpiner Bodenalgen. Österreichische Botanische Zeitschrift III, 402-499.

RĚTOVSKÝ, R. \& KLÁŠTERSKÁ. (I96I). Study of the growth and development of Chlorella populations as a whole. V. The influence of magnesium sulphate on autospore formation. Folia Microbiologica, Praha 6, I I 5-I 26.

Saccardo, P. A. \& Traverso, J. B. (I9I I). Prototheca zopfii (Saccharomycetaceae). Sylloge Fungorum 20, 525 .

SiERrA, G. (1957). A simple method for the detection of lipolytic activity of micro-organisms and some observations on the influence of the contact between cells and fatty substances. Antonie van Leeuwenhoek 23, 15-22.

Skerman, V. B. D. (1967). A Guide to the Genera of Bacteria, 2nd edn. Baltimore: Williams and Wilkins Co.

Society of American Bacteriologists. (1957). Manual of Microbiological Methods. Edited by Committee on Bacteriological Technic. New York: McGraw-Hill.

SOEDER, C. J. (1963). Weitere zellmorphologische und physiologische Merkmale von Chlorellaarten. In Studies of Microalgae and Photosynthetic Bacteria. Edited by J. Ashida. pp. 2I-34. 'Tokyo: University of Tokyo Press.

Stanier, R. Y., Palleroni, N. J. \& Doudoroff, M. (i966). The aerobic pseudomonads: a taxonomic study. Journal of General Microbiology 43, I 59-27I. 
Tamma, H., Morimura, Y., Yokota, M. \& Kunieda, R. (196r). Mode of nuclear division in synchronous cultures of Chlorella: comparison of various methods of synchronization. Plant and Cell Physiology, Tokyo 2, 383-403.

TARBet, J. E., Wright, E. T. \& Newcomer, V. D. (1952). Experimental coccidioidal granuloma. Developmental stages of sporangia in mice. American Journal of Pathology 28, 90I-917.

Tubaki, K. \& Soneda, M. (1959). Cultural and taxonomical studies on Prototheca. Nagao 6, 25-33. West, G. S. (1916). Algae, vol. I. Cambridge University Press.

\section{EXPLANATION OF PLATES}

Plate I

Fig. I. Normal young colony on GDY agar. $\times$ I00.

Fig. 2. Colony with irregular halo on GDY agar. $\times 50$.

Fig. 3. Edge of an old colony on GDY agar. Spherical peripheral cells have degenerated to give a 'watery' edge. $\times 175$.

Fig. 4 to 9. Sporangial bursts of Hyalochlorella marina $66-6$ A. Note sporangial wall (S). $\times 500$.

Fig. 10. Sporangial wall. $\times 1400$.

Fig. I I. Tripartite sporangium. $\times$ I600.

Fig. 12 to I4. Motile preautospores. Five preautospores are outside of sporangial wall while two remain inside. $\times 1000$.

\section{Plate 2}

Fig. 15 to 21 . Growth of an individual (Hyalochlorella marina 66-6A) under the constant environmental conditions of a perfusion chamber and photographed with phase contrast microscopy. $\times 2200$. Insets are of Feulgen-acetocarmine stained cells of comparable stages. $\times$ I 400 .

Fig. 15. Uninucleate autospore with nucleolus (NE).

Fig. I6. Binucleate stage with vacuole. Only one nucleus (NU) is obvious in the phase contrast photograph.

Fig. 17. Optical section through the centre of a developing sporangium showing vacuolar centre (VC).

Fig. I8. Precleavage sporangium with enlarged nuclei (NU) lacking nucleoli.

Fig. I9. Immature sporangium with incomplete cleaveage lines.

Fig. 20. Mature sporangium with complete cleavage lines (CL) delimiting preautospores.

Fig 2I. Ruptured sporangium and uninucleate autospores. 

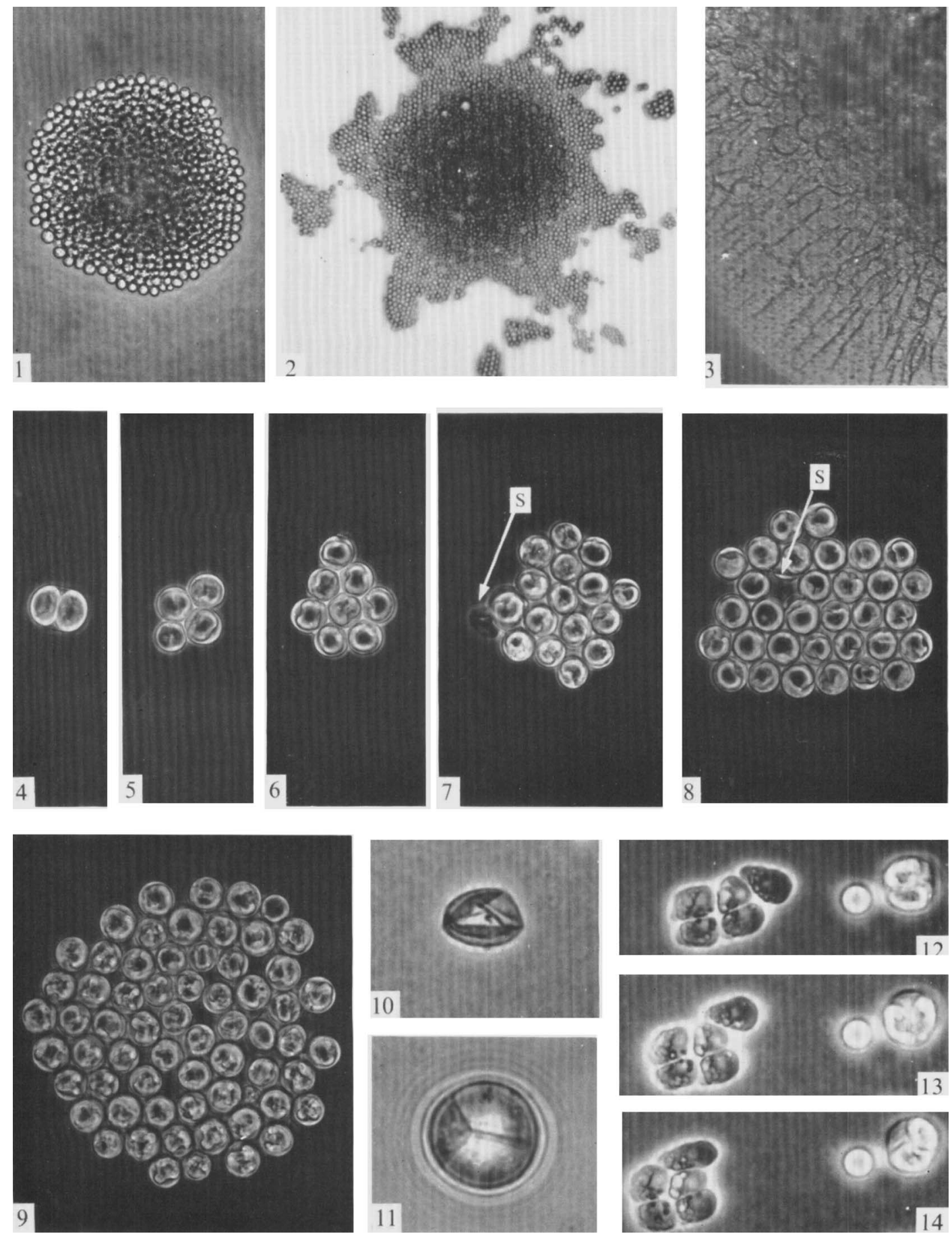
Journal of General Microbiology, Vol. 62, No. 2

Plate 2
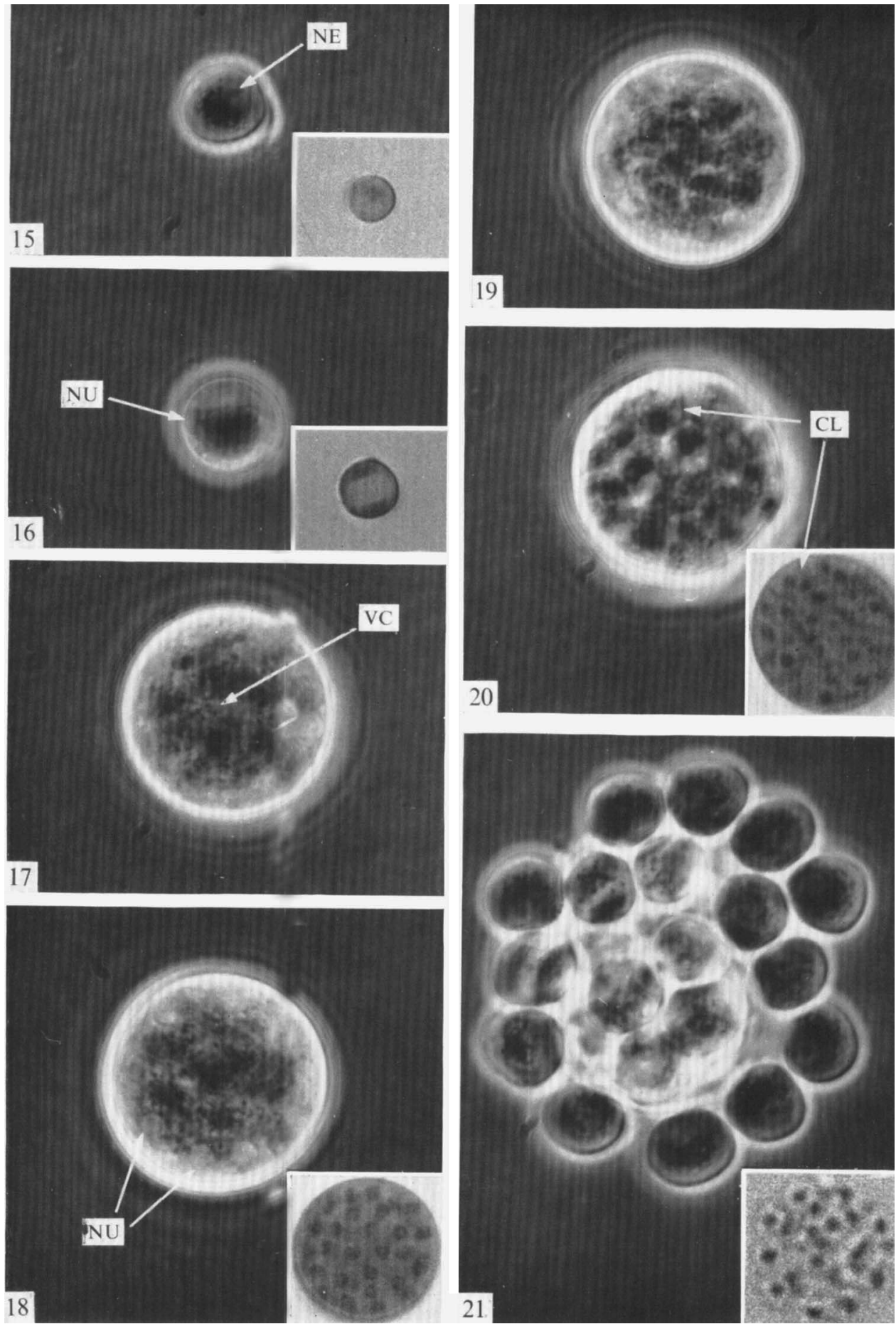

R. O. POYTON 